\title{
Stability of Flavonoid, Carotenoid, Soluble Sugar and Vitamin C in 'Cara Cara' Juice during Storage
}

\author{
Qi Lu ${ }^{1,2}$, Lu Li ${ }^{1}$, Shujin Xue ${ }^{1}$, De Yang ${ }^{1}$ and Shaohua Wang ${ }^{1, *}$ \\ 1 Institute of Agro-Products Processing and Nuclear Agricultural Technology, Hubei Academy of Agricultural \\ Sciences, Wuhan 430064, China; luqihzau@126.com (Q.L.); Lulilu2662@163.com (L.L.); \\ xsj2000@163.com (S.X.); yde0537@163.com (D.Y.) \\ 2 College of Food Science and Technology, Huazhong Agricultural University, Wuhan 430070, China \\ * Correspondence: shaohuawangfood@sina.com
}

Received: 5 August 2019; Accepted: 10 September 2019; Published: 16 September 2019

check for updates

\begin{abstract}
In view of understanding the stability of sterilized 'Cara Cara' juice during storage, the changes of specific quality parameters (flavonoid, carotenoid, vitamin C, soluble sugar and antioxidant activities) of 'Cara Cara' juice were systematically investigated over the course of 16 weeks in storage at $4,20,30$ and $40^{\circ} \mathrm{C}$. Total flavonoid and carotenoid indexes showed slight degradation at each temperature, while vitamin $\mathrm{C}$ and soluble sugar degraded intensively, especially at $40^{\circ} \mathrm{C}$ storage with a great amount of HMF (5-hydroxymethylfurfural) accumulated. There were 29 carotenoids detected during storage, including carotenes and carotenoid esters. Carotenes were kept stable, while the degradations of carotenoid esters were fitted by biexponential function. Carotenoid ester group 2 contained epoxy structures that quickly decreased in the first four weeks at all storage temperatures, while the ester group 1 (belonged to $\beta$-cryptoxanthin ester) was degraded gradually. The 13- or 15-cis-lycopene, isomerized from all-(trans)-lycopene, increased with storage time at each temperature. Total flavonoid and carotenoid indexes in stored 'Cara Cara' juice were positively correlated with hydrophilic and lipophilic antioxidant abilities.
\end{abstract}

Keywords: 'Cara Cara' juice; storage; hydrophilic and lipophilic antioxidant; carotenoid; flavonoid; degradation

\section{Introduction}

Citrus juice possesses an attractive natural color, with a sweet and sour taste, making it popular with food consumers around the world [1]. Intake of citrus juice is confirmed to be effective for prevention of human chronic-degenerative diseases [2,3], and micronutrients of carotenoids, flavonoids and ascorbic acid are responsible for the physiological function of citrus juice [4,5]. Orange cv. 'Cara Cara', a bud mutation of navel orange (Citrus. sinensis L. Osbeck) originating in Venezuela in the 1980s, displays an attractive bright red color due to the accumulation of lycopene [6], and it has been widely planted in China [7]. Changes of food sensorial and nutritional quality during storage limits the date of food consumption. 'Cara Cara' juice products have not been commercially available in China, and the nutritional changes of 'Cara Cara' juice during storage have not been investigated.

Citrus juice products are usually exposed to various temperatures in the food supply chain. It is necessary to investigate the changes of carotenoid, flavonoid and ascorbic acid during storage at different temperatures, since these components play an important role in the healthy function of citrus juice. Rapisarda reported that the flavanone in sweet orange juice decreased about $50 \%$ after storage at $4{ }^{\circ} \mathrm{C}$ for 20 days [8], while Klimczak found that the flavanone in commercial pure orange juice was rather stable during storage with only minor changes observed [9]. Apigenin-6,8-di-C-glucoside, narirutin-4'-O-glucoside, narirutin, hesperidin and didymi were confirmed as typical flavonoids in 
'Cara Cara' juice [10]. There is little information on the influence of storage temperature and duration on flavonoid content in 'Cara Cara' juice.

Due to the complex composition of carotenoids in oranges, the saponification procedure has typically been applied to simplify the analysis, by transferring esterified carotenoids into free cartoenoids [11,12]. The stability of carotenoids can be influenced by temperature, time, and the availability of light and oxygen [13]. Previous studies have mainly focused on the degradation of free carotenoids during storage $[12,14]$, while the change of carotenoid esters in citrus juice during storage has not been reported. There have been 19 carotenoid esters inferred in 'Cara Cara' fruit, with the 9-cis-violaxanthin ester confirmed as the dominant component [7], and esterified $\beta$-cryptoxanthin considered to be the most stable ester during thermal treatment [15]. The change of free and esterified cartoenoids in 'Cara Cara' juice needs to be further explored.

Non-enzymatic browning, frequently observed in citrus juice, plays an important role in the color, flavor and nutritional quality of the stored citrus juice [1]. Non-enzymatic browning is also strongly connected to the degradation of ascorbic acid and sugar, with HMF (5-hydroxymethylfurfural) detected as the indicator [1]. A previous report confirmed that vitamin $C$ in citrus juice was affected by the storage temperature and duration [9]. However, changes of flavonoid, carotenoids, vitamin $\mathrm{C}$ and sugar in 'Cara Cara' juice during storage at different temperatures have been not investigated, especially in terms of carotenoid esters.

We, therefore, carried out a pilot study to investigate the changes of carotenoid, flavonoid and vitamin C in 'Cara Cara' juice during 16 weeks of storage at different temperatures. In addition, the lipophilic and hydrophilic antioxidant abilities of stored 'Cara Cara' juice were analyzed.

\section{Materials and Methods}

\subsection{Sample Preparation}

'Cara Cara' juice $\left(15.3^{\circ}\right.$ Brix, $\mathrm{pH} 3.70$, titratable acidity $\left.0.93 \%\right)$ was obtained from commercial matured fruit of Orange cv. Cara Cara, harvested from the Fujian province of China in December 2017. The fresh 'Cara Cara' fruit $(50 \mathrm{~kg})$ was immediately peeled and squeezed with a fruit extruder. Half of the crude juice was stored at $-80^{\circ} \mathrm{C}$ and half was directly subjected to a rapid thermal sterilization. Specifically, 'Cara Cara' juice was boiled in a stainless-steel container with an electronic thermometer (F1, invisible, Guangdong, China) monitoring the internal temperature of the 'Cara Cara' juice $\left(98^{\circ} \mathrm{C}\right.$, $16 \mathrm{~s})$. The sterilized juice was immediately filled into glass bottles $(50 \mathrm{~mL})$. These bottles and their caps were disinfected before use. After cooling, the juice was stored at 4, 20, 30 and $40{ }^{\circ} \mathrm{C}$ for 16 weeks without lights. At each sampling time, three bottles of juice were taken and frozen at $-80^{\circ} \mathrm{C}$ until use.

\subsection{Chemicals and Reagents}

The standards of narirutin, hesperidin, didymin, lycopene, $\beta$-carotene, fructose, glucose and sucrose were acquired from Yuanye Bio-Technology Co., Ltd (Shanghai, China). Phytoene and violaxanthin were purchased from CaroteNature (Lupsingen, Switzerland) and Sigma (St. Louis, MO, USA), respectively. ABTS $^{+}\left(2,2^{\prime}\right.$-azino-bis(3-ethylbenzothiazoline-6-sulfonic acid)) and 2,2-diphenyl-1-picrylhydrazyl (DPPH) were purchased from Yuanye Bio-Technology Co., Ltd (Shanghai, China). High performance liquid chromatography purity solvents, including methyl tert-butyl ether (MTBE), methanol and hexane were obtained from Thermo Fisher Scientific (Leicestershire, UK). Other analytical grade chemicals, such as ethanol, hexane and sodium hydroxide were bought from Sinopharm Chemical Reagent Co., Ltd (Shanghai, China).

\subsection{Extraction of Carotenoid from 'Cara Cara' Juice}

The extraction of carotenoids from 'Cara Cara' juice was performed according to our previous study [15]. Briefly, 'Cara Cara' juice $(10 \mathrm{~mL})$ was homogenized with $10 \mathrm{~mL}$ ethanol/hexane $(4: 3, v / v, 0.1 \%$ butylated hydroxytoluene) by stirring at $700 \mathrm{rpm}$ for $0.5 \mathrm{~h}$. The mixture was subsequently centrifuged 
$(19,360 \times g, 4 \mathrm{~min})$ to obtain the liquid phase. After extraction of the residue twice, all the liquid phases were combined, and then washed by separatory funnel to collect the non-polar supernatants. The obtained supernatant was evaporated to dryness, then re-dissolved by methyl tert-butyl ether and filtered $(0.22 \mu \mathrm{m}$ polytetrafluoroethylene filter) for the analysis of carotenoids.

\subsection{Extraction of Flavonoid from 'Cara Cara' Juice}

Flavonoids in 'Cara Cara' juice were extracted based on our previous study, with minor modification [15]. Briefly, 'Cara Cara' juice $(1 \mathrm{~mL})$ was homogenized with the extract solvent ( $85 \%$ aqueous ethanol containing $0.1 \% \mathrm{HCl}, 4 \mathrm{~mL}$ ) by an ultrasonic cleaner (KQ-500E, Kun Shan Ultrasound Instrument Co., Jiangsu, China) at $40 \mathrm{kHz}$ for $30 \mathrm{~min}$. The mixture was centrifuged $(9680 \times g$ for $5 \mathrm{~min}$ ) and filtered through $0.22 \mu \mathrm{m}$ PTFE filter for further analysis.

\subsection{Antioxidant Assays}

Based on a previous study [16], the antioxidant abilities of hydrophilic and lipophilic extracts in 'Cara Cara' juice were measured by DPPH and $\mathrm{ABTS}^{+}$assays. The DPPH activity was evaluated as previously described [10], and the final results were expressed as $\mu \mathrm{mol}$ ascorbic acid equivalent (AAE) per milliliter 'Cara Cara' juice ( $\left.\mu \mathrm{mol} \mathrm{AAE} / \mathrm{mL}, y=0.0012 x+0.0438, R^{2}=0.9902\right)$. The $\mathrm{ABTS}^{+}$assay was conducted according to the existing protocol [17], while the final results were expressed as $\mu \mathrm{mol}$ Trolox equivalent (TE) per milliliter 'Cara Cara' juice ( $\mu \mathrm{mol} \mathrm{TE} / \mathrm{mL}, y=0.3025 x+0.076, R^{2}=0.9807$ ). The hydrophilic and lipophilic capacities of stored 'Cara Cara' juice were calculated every four weeks $(0,4,8,12,16$ weeks).

\subsection{Analysis of Carotenoids and Flavonoids in 'Cara Cara' Juice}

The analysis of carotenoids was performed on HPLC (2695 system, Waters Corp., Milford, MA, USA) using a $\mathrm{C}_{30}$ reversed phase column $(250 \times 4.6 \mathrm{~mm}, 5 \mu \mathrm{m}$; YMC, Inc. Wilmington, NC, USA) and flavonoids were separated on the Waters Acquity UPLC system (Waters Corp., Milford, MA, USA) with a BEH $C_{18}$ column $(100 \mathrm{~mm} \times 2.1 \mathrm{~mm}, 1.7 \mu \mathrm{m})$. Their chromatographic separation, identification and quantification procedures were conducted based on our previous study [15]. The content of flavonoids in 'Cara Cara' juice during storage were analyzed every four weeks $(0,4,8,12,16$ weeks), and the sampling times for carotenoids quantification in stored 'Cara Cara' juice were set at 0, 2, 4, 6, 8, 12 and 16 weeks.

\subsection{Ascorbic Acid Measurement}

The ascorbic acid was determined by the titration method, using 2,6-dichlorophenolindophenol dye [18].

\subsection{Sugar Measurement}

Modified from a previous study [19], the soluble sugar in 'Cara Cara' juice was determined by HPLC (2695 system, Waters Corp., Milford, MA, USA) with 2414 refractive index detector (Waters, Milford, MA, USA), and an inertsil $\mathrm{NH}_{2}$ column $(250 \times 4.6 \mathrm{~mm}, 5 \mu \mathrm{m}$; Dikma Technologies Inc., Beijing, China) was used for sugar separation. Zinic acetate solution $(21.9 \%, 0.1 \mathrm{~mL})$ and potassium ferrocyanide solution $(10.6 \%, 0.1 \mathrm{~mL})$ were added in 'Cara Cara' juice $(1 \mathrm{~mL})$ to precipitated proteins. Afterwards, distilled water was added to $2 \mathrm{~mL}$, and centrifuged to obtain the supernatant for HPLC analysis. Mobile phase was acetonitrile/water (75/25) and the HPLC operating conditions were set as: injection volume $20 \mu \mathrm{L}$; column temperature $40^{\circ} \mathrm{C}$; detector temperature $40^{\circ} \mathrm{C}$; flow rate $1 \mathrm{~mL} / \mathrm{min}$. The contents of sugar in 'Cara Cara' juice during storage were detected every two weeks $(0,2,4,6,8$, $10,12,14,16$ weeks). 


\subsection{Statistical Analysis}

All the experiments were conducted in triplicate, and the data were presented as mean \pm standard deviation of triplicate independent experiments. One-way analysis of variance (ANOVA) was applied to compare the means, and the differences between the means were analyzed by Duncan's multiple range tests at a significance level of 0.05 . Correlation analysis of the matrix was analyzed by Pearson correlation coefficient ( $t$-test). All statistical analyses were processed by IBM SPSS Statistics version 20.0. Carotenoid compounds were quantified in 'Cara Cara' juice during the 16 weeks of storage at different temperatures. The data were arranged to have carotenoid components at different temperatures as objects (rows) and storage weeks as variables (columns) and processed by principal component analysis (XLSTAT 2016, Addinsoft, New York, NY, USA). The results were presented with graphs plotting the projections of the units onto the components, and the loadings of the variables. Correlation between variables was evaluated by Pearson's correlation coefficient [20].

\section{Results and Discussion}

\subsection{Changes of Flavonoids in 'Cara Cara' Juice}

Based on our previous study $[10,15]$, flavonoids were confirmed to be the dominant phenolic compounds in 'Cara Cara' juice, including apigenin-6,8-di-C-glucoside, narirutin-4'-O-glucoside, narirutin, hesperidin and didymin. The content changes of individual flavonoids are shown in Table 1. Compared with a previous study [21], the contents of narirutin and hesperidin reported in this study were relatively higher. Each individual flavonoid was not significantly changed during storage at $4{ }^{\circ} \mathrm{C}$. Didymin and narirutin were stable with no significant decrease observed at all storage temperatures, while other flavonoids (apigenin-6,8-di-C-glucoside, narirutin-4'-O-glucoside, hesperidin) were significantly degraded during storage at 20,30 and $40{ }^{\circ} \mathrm{C}$. The degradation of flavonoids in fruit juice was probably associated with the peroxidase activity, which might not be completely inactive by sterilization [22].

Table 1. Changes in the content of flavonoids $(\mu \mathrm{g} / \mathrm{mL})$ in 'Cara Cara' juice during 16 weeks of storage at different temperatures.

\begin{tabular}{|c|c|c|c|c|c|c|}
\hline Weeks & $\begin{array}{c}\text { Apigenin-6,8- } \\
\text { di-C-Glucoside }\end{array}$ & $\begin{array}{l}\text { Narirutin-4'-O- } \\
\text { Glucoside }\end{array}$ & Narirutin & Hesperidin & Didymin & $\begin{array}{l}\text { Total Flavonoid } \\
\text { Index }\end{array}$ \\
\hline \multicolumn{7}{|c|}{$4{ }^{\circ} \mathrm{C}$} \\
\hline 0 & $30.37 \pm 2.47 \mathrm{a}$ & $30.43 \pm 1.69 \mathrm{a}$ & $140.62 \pm 6.47 \mathrm{a}$ & $620.22 \pm 22.86 a$ & $76.15 \pm 3.24 \mathrm{a}$ & $897.79 \pm 36.73 a$ \\
\hline 4 & $26.46 \pm 0.48 \mathrm{a}$ & $27.41 \pm 1.93 \mathrm{a}$ & $137.64 \pm 12.29 \mathrm{a}$ & $618.98 \pm 29.43 \mathrm{a}$ & $76.45 \pm 2.67 \mathrm{a}$ & $886.94 \pm 46.80 \mathrm{a}$ \\
\hline 8 & $27.48 \pm 1.36 \mathrm{a}$ & $26.77 \pm 2.38 \mathrm{a}$ & $136.84 \pm 13.91 \mathrm{a}$ & $601.63 \pm 16.38 \mathrm{a}$ & $76.16 \pm 5.33 \mathrm{a}$ & $868.88 \pm 39.39 a$ \\
\hline 12 & $25.49 \pm 1.56 \mathrm{a}$ & $25.93 \pm 2.58 \mathrm{a}$ & $134.51 \pm 6.17 \mathrm{a}$ & $583.72 \pm 5.90 \mathrm{a}$ & $74.34 \pm 3.85 a$ & $843.99 \pm 20.06 \mathrm{a}$ \\
\hline 16 & $25.04 \pm 0.47 \mathrm{a}$ & $25.52 \pm 1.42 \mathrm{a}$ & $129.25 \pm 4.35 \mathrm{a}$ & $567.65 \pm 13.95 \mathrm{a}$ & $72.91 \pm 1.34 \mathrm{a}$ & $820.37 \pm 21.53 \mathrm{a}$ \\
\hline \multicolumn{7}{|c|}{$20^{\circ} \mathrm{C}$} \\
\hline 0 & $30.37 \pm 2.47 \mathrm{a}$ & $30.43 \pm 1.69 a$ & $140.62 \pm 6.47 \mathrm{a}$ & $620.22 \pm 22.86 a$ & $76.15 \pm 3.24 \mathrm{a}$ & $897.79 \pm 36.73 a$ \\
\hline 4 & $25.63 \pm 2.35 \mathrm{ab}$ & $26.86 \pm 3.25 \mathrm{ab}$ & $136.82 \pm 4.57 \mathrm{a}$ & $614.16 \pm 8.56 \mathrm{ab}$ & $75.28 \pm 4.47 a$ & $878.75 \pm 23.20 \mathrm{a}$ \\
\hline 8 & $25.35 \pm 1.30 \mathrm{ab}$ & $24.66 \pm 0.92 \mathrm{ab}$ & $133.32 \pm 1.82 \mathrm{a}$ & $592.5 \pm 17.68 \mathrm{ab}$ & $72.73 \pm 2.45 a$ & $848.56 \pm 24.17 \mathrm{a}$ \\
\hline 12 & $23.37 \pm 0.53 b$ & $24.65 \pm 0.62 \mathrm{ab}$ & $125.89 \pm 10.60 \mathrm{a}$ & $574.42 \pm 10.99 \mathrm{ab}$ & $74.45 \pm 1.34 \mathrm{a}$ & $822.78 \pm 24.08 \mathrm{a}$ \\
\hline 16 & $21.25 \pm 1.24 b$ & $21.77 \pm 1.45 b$ & $126.78 \pm 5.32 \mathrm{a}$ & $556.75 \pm 12.03 \mathrm{~b}$ & $71.42 \pm 1.38 \mathrm{a}$ & $797.95 \pm 21.42 \mathrm{a}$ \\
\hline \multicolumn{7}{|c|}{$30^{\circ} \mathrm{C}$} \\
\hline 0 & $30.37 \pm 2.47 \mathrm{a}$ & $30.43 \pm 1.69 \mathrm{a}$ & $140.62 \pm 6.47 \mathrm{a}$ & $620.22 \pm 22.86 a$ & $76.15 \pm 3.24 \mathrm{a}$ & $897.79 \pm 36.73 a$ \\
\hline 4 & $27.33 \pm 3.03 \mathrm{a}$ & $26.35 \pm 1.65 \mathrm{ab}$ & $133.14 \pm 6.59 \mathrm{a}$ & $603.28 \pm 17.21 \mathrm{ab}$ & $74.15 \pm 1.27 \mathrm{a}$ & $864.25 \pm 29.75 \mathrm{a}$ \\
\hline 8 & $26.25 \pm 1.73 \mathrm{a}$ & $27.06 \pm 1.25 \mathrm{ab}$ & $128.52 \pm 12.45 \mathrm{a}$ & $569.28 \pm 8.79 \mathrm{ab}$ & $73.10 \pm 5.83 a$ & $824.21 \pm 30.05 \mathrm{a}$ \\
\hline 12 & $23.71 \pm 0.66 \mathrm{a}$ & $22.91 \pm 0.92 \mathrm{~b}$ & $121.33 \pm 5.08 \mathrm{a}$ & $567.69 \pm 10.58 \mathrm{ab}$ & $73.92 \pm 0.75 a$ & $809.56 \pm 17.99 a$ \\
\hline 16 & $22.35 \pm 2.62 \mathrm{a}$ & $23.26 \pm 2.98 b$ & $122.57 \pm 9.82 \mathrm{a}$ & $550.59 \pm 16.56 b$ & $70.70 \pm 3.23 \mathrm{a}$ & $789.47 \pm 35.21 \mathrm{a}$ \\
\hline \multicolumn{7}{|c|}{$40^{\circ} \mathrm{C}$} \\
\hline 0 & $30.37 \pm 2.47 \mathrm{a}$ & $30.43 \pm 1.69 \mathrm{a}$ & $140.62 \pm 6.47 \mathrm{a}$ & $620.22 \pm 22.86 \mathrm{a}$ & $76.15 \pm 3.24 \mathrm{a}$ & $897.79 \pm 36.73 \mathrm{a}$ \\
\hline 4 & $24.63 \pm 1.45 \mathrm{ab}$ & $26.19 \pm 1.55 \mathrm{ab}$ & $131.68 \pm 10.37 \mathrm{a}$ & $594.84 \pm 14.22 \mathrm{ab}$ & $74.07 \pm 4.63 \mathrm{a}$ & $851.41 \pm 32.22 \mathrm{a}$ \\
\hline 8 & $25.48 \pm 0.93 \mathrm{ab}$ & $26.58 \pm 1.12 \mathrm{ab}$ & $132.44 \pm 4.75 \mathrm{a}$ & $579.33 \pm 15.21 \mathrm{ab}$ & $72.25 \pm 2.24 \mathrm{a}$ & $836.08 \pm 24.25 \mathrm{a}$ \\
\hline 12 & $23.36 \pm 1.23 \mathrm{~b}$ & $24.88 \pm 1.69 \mathrm{ab}$ & $130.66 \pm 8.46 \mathrm{a}$ & $570.12 \pm 11.13 \mathrm{ab}$ & $73.33 \pm 1.68 \mathrm{a}$ & $822.35 \pm 24.19 a$ \\
\hline 16 & $23.59 \pm 2.43 \mathrm{ab}$ & $24.09 \pm 1.35 b$ & $127.59 \pm 10.68 \mathrm{a}$ & $552.17 \pm 12.54 \mathrm{~b}$ & $71.29 \pm 3.36 \mathrm{a}$ & $798.73 \pm 30.36 \mathrm{a}$ \\
\hline
\end{tabular}

Values are expressed as mean $\pm \mathrm{SD}, n=3$. Values followed by different letters in the columns are significantly different (Duncan's multiple range tests, $p<0.05$ ). Total flavonoid index represents the sum of individual quantified flavonoid concentrations. 
HMF eluted with flavonoids on UPLC was only detected at $40{ }^{\circ} \mathrm{C}$ storage, with a slow accumulation in the first 12 weeks $\left(y=0.006 x+0.012, R^{2}=0.778\right)$ and a rapid increase was found in the last four weeks $\left(y=0.071 x+0.833, R^{2}=0.871\right)$, with the final content reaching $285.74 \mu \mathrm{g} / \mathrm{mL}$. HMF is generated from the decomposition of vitamin $C$ or sugar degradation, and it is typically used to evaluate the deterioration severity of juice $[23,24]$.

\subsection{The Changes of Carotenoids in 'Cara Cara' Juice}

\subsubsection{Carotenoid Composition}

Citrus was reported as a natural carotenoids source [25]. A total of 29 peaks were detected by HPLC-DAD (Figure 1), and they were identified according to our previous studies [7,15]. Peaks 1 to 27 existed in the sterilized 'Cara Cara' juice before storage, and they were inferred as mutatoxanthin, zeaxanthin, $\beta$-cryptoxanthin, luteoxanthin-C14:0, 9-cis-violaxthin-C18:1, $\zeta$-carotene, violaxthin-C16:0, luteoxanthin-C16:0, $\beta$-carotene, unknown ester, 9-cis-antheraxanthin-C16:0, 9-cis-violaxthin-C12:0-C14:0, $\beta$-cryptoxanthin-C12:0, $\beta$-cryptoxanthin-C16:1, 9-cis-violaxthin-C14:0-C14:0, $\beta$-cryptoxanthin-C14:0, 13- or 15-cis- $\beta$-cryptoxanthin-C18:1, a mixture of 9-cis-violaxthin-C14:0-C16:0 and 9-cis-violaxthin-C16:0-C18:1, 13- or 15-cis-lycopene, $\quad \beta$-cryptoxanthin-C16:0, antheraxanthin-C14:0-C16:0, 9-cis-antheraxanthin-C16:0-C16:0, lycopene, phytoene, cis-phytofluene 1 , cis-phytofluene 2 and cis-phytofluene 3, respectively. Peaks 28 and 29 were the newly formed compounds, in trace amounts, during storage at $40{ }^{\circ} \mathrm{C}$ for 8 weeks, and they were identified as 13- or 15 -cis- $\beta$-cryptoxanthin and cis-phytofluene 4 , based on their mass spectrometry, elution order and ultraviolet-visible spectra [15].

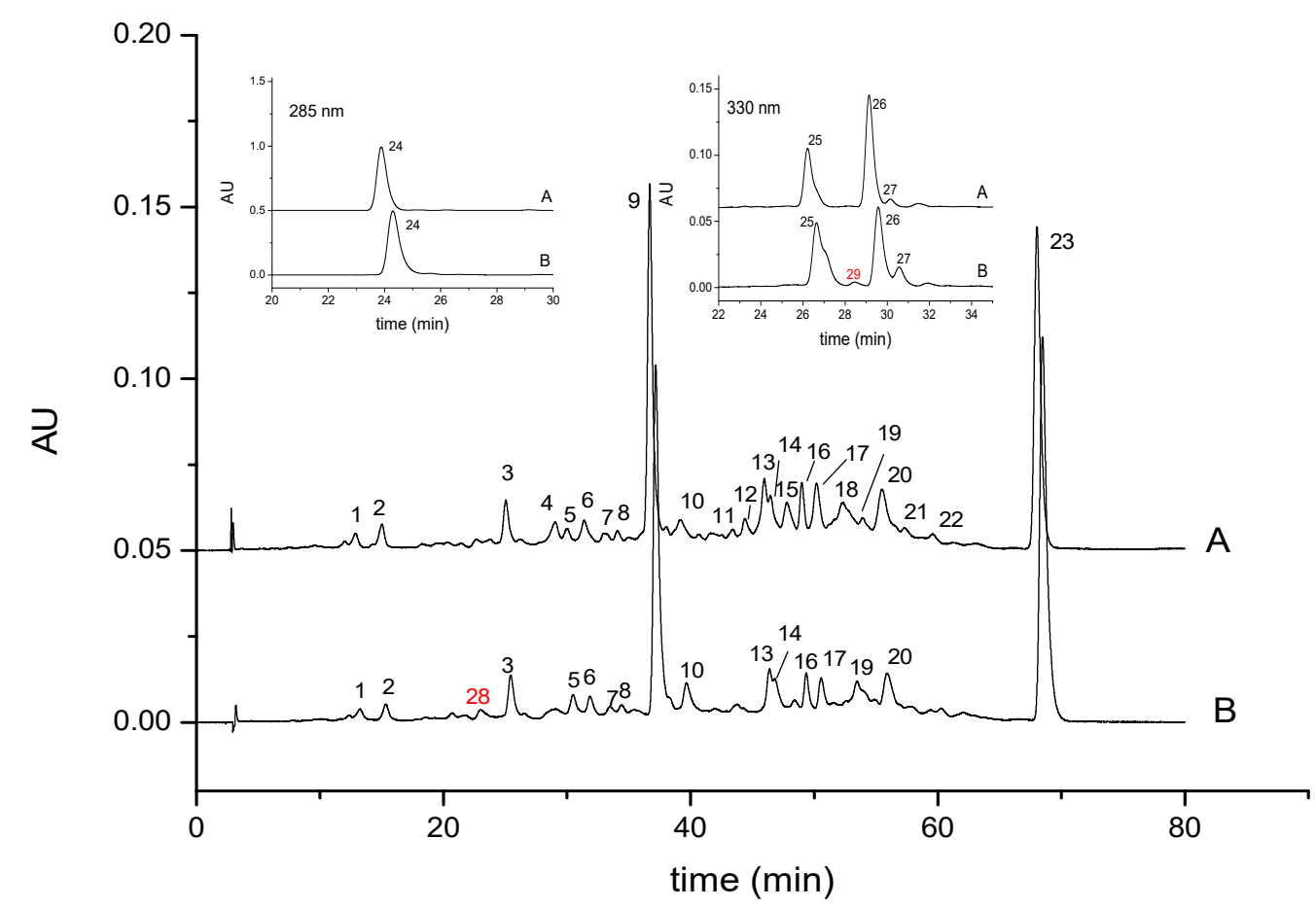

Figure 1. HPLC chromatograms $(450 \mathrm{~nm})$ of carotenoids detected in 'Cara Cara' juice before (A) and after 16 weeks of storage at $40{ }^{\circ} \mathrm{C}$ (B); Peaks 24-29 displayed no significant absorbance at $450 \mathrm{~nm}$, while distinct absorption was detected at $285 \mathrm{~nm}$ (peak 24) and $350 \mathrm{~nm}$ (peak 25-29). AU represents the absorbance unit of carotenoid.

It was confirmed that $\beta$-cryptoxanthin esters were more stable than their corresponding free forms [26], whereas epoxy-carotenoid esters were liable to degrade in orange juice, since 5,6-epoxy 
xanthophylls could be triggered into their 5,8-epoxy counterparts with a trace amount of acid $[25,26]$. Changes of carotenoids in 'Cara Cara' juice could be observed by comparing the HPLC chromatograms before and after the storage. Several epoxy-carotenoid esters (peaks 4, 11, 12, 15, 18, 21 and 22; luteoxanthin-C14:0, 9-cis-antheraxanthin-C16:0, 9-cis-violaxthin-C12:0-C14:0, 9-cis-violaxthin-C14:0-C14:0, a mixture of 9-cis-violaxthin-C14:0-C16:0 and 9-cis-violaxthin-C16:0-C18:1, antheraxanthin-C14:0-C16:0and 9-cis-antheraxanthin-C16:0-C16:0) disappeared completely during the storage. The absence of epoxy-carotenoid esters in 'Cara Cara' juice was correlated with its long storage period [25]. Carotenoid esters in 'Cara Cara' juice were classified in different groups to simplify their quantification. Briefly, $\beta$-cryptoxanthin esters including peaks 13, 14, 16, 17 and 20 were categorized as ester group 1; epoxy carotenoid esters including peaks 4, 5, 7, 8, 11, 12, 15, 18, 21 and 22 were sorted as ester group 2; Peak 10 disappeared after saponification procedure, but its structure could not be inferred by MS fragments and UV-Vis spectra. Therefore, peak 10 was defined as unknown ester and was classified as ester group 3. The content of carotenoids in 'Cara Cara' juice during storage are presented in the Supplementary Materials (Table S1).

\subsubsection{Carotenoid Degradation}

The total carotenoid index in the sterilized 'Cara Cara' juice before storage was $309.06 \pm 11.28 \mu \mathrm{g} / \mathrm{mL}$, and the dominate compound was phytoene $(69.78 \%)$, followed by total phytofluene $(19.98 \%)$, carotenoid esters $(4.15 \%), \beta$-carotene $(3.39 \%)$, lycopene $(1.69 \%)$, and others $(1.01 \%)$. The total carotenoids showed a declining trend at all storage temperatures, but their degradations did not reach a significant level. Carotenes of phytoene, $\beta$-carotene and lycopene were kept stable during storage, while all-trans-phytofluenes and cis-phytofluenes were irregularly fluctuated. Matrix protection might have been responsible for the stability of the carotenes in 'Cara Cara' juice $[15,27,28]$. Carotenoid ester, especially ester group 2, decreased dramatically during storage, and this might be related to their unstable xanthophyl structure which could be easily isomerized and degraded. The content changes of ester group 1 and ester group 2 in 'Cara Cara' juice are presented in Figure 2. Their degradation was fitted by biexponential function (Equation (1)) and the detailed kinetic parameters are presented in the Supplementary Materials (Figures S1 and S2).

$$
y_{t}=y_{\infty}+A_{1} \exp (-\alpha t)+A_{2} \exp (-\beta t)
$$

$\mathrm{y}_{\mathrm{t}}$, is the carotenoid concentration at real time; $\mathrm{y}_{\infty}$, is the theoretical concentration of carotenoid at infinite time. $A_{1}$ and $A_{2}$ represent the pre-exponential factors; $\alpha$ and $\beta$, are the observed rate constants for fast and slow degradation. Biexponential degradation of carotenoid indicated both irreversible (degraded into volatiles or epoxides) and reversible (isomerization) degradation were involved, and this degradation form was also observed during thermal treatment of carotenoid juices [15,29]. Ester group 2 was quickly decreased in the first four weeks at all storage temperatures (Figure 2), while ester group 1 was degraded gradually. Therefore, the storage time of 'Cara Cara' juice could be estimated by combining the degrading rates of ester group 1 and ester group 2 at each temperature, and this issue will be explored in our future research. 


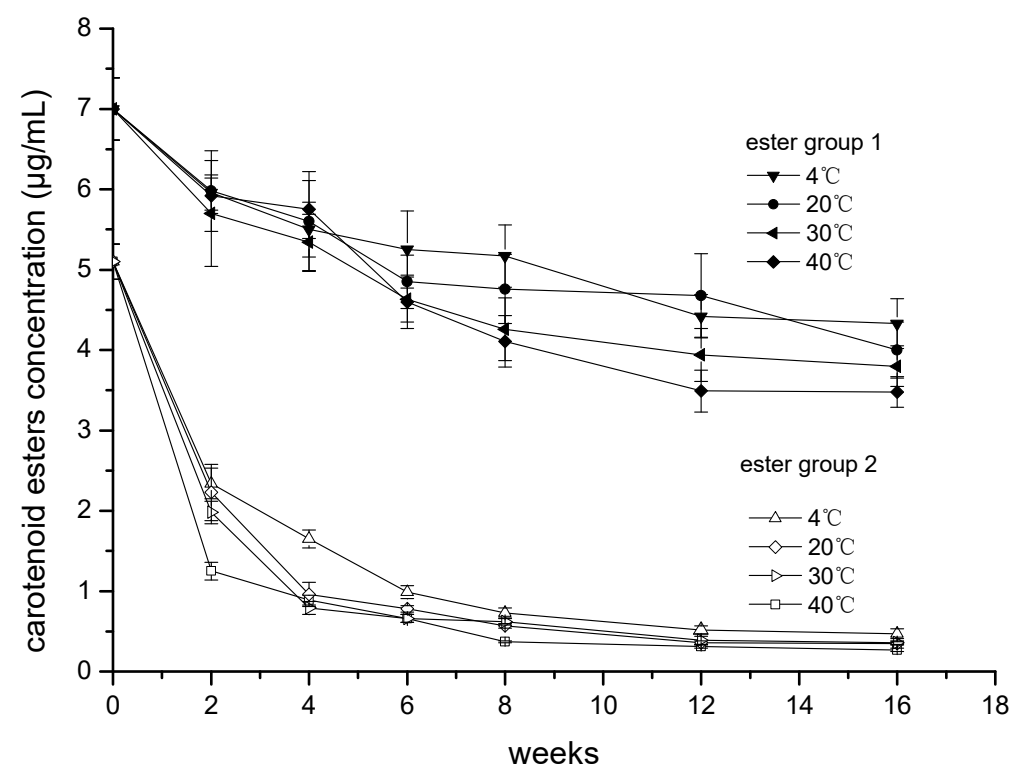

Figure 2. Changes in the content of ester group 1 and ester group $2(\mu \mathrm{g} / \mathrm{mL})$ in 'Cara Cara' juice during 16 weeks of storage at different temperature.

\subsubsection{PCA Analysis}

PCA was investigated to understand the segregation and correlation among carotenoid compounds in 'Cara Cara' juice at all storage temperatures. According to the PCA results, three principal components were obtained to account for the total variance. PC1 and PC2 accounted for $69.02 \%$ and $15.77 \%$ of the total variance, respectively. Carotenoid compounds, decreased with the storage time (Table S1), were sorted in the same group and they were strongly and positively correlated with PC1 (Figure 3A). Other compounds including 13 - or 15-cis-lycopenes $\left(4,20,30,40{ }^{\circ} \mathrm{C}\right)$, cis-phytofluenes $(4,20,30$, $\left.40^{\circ} \mathrm{C}\right)$, ester groups $3\left(4,20,30,40^{\circ} \mathrm{C}\right)$ and $\zeta$-carotenes $\left(30,40^{\circ} \mathrm{C}\right)$ were classified into the other two groups. The 13- or 15-cis-lycopene, derived from all-(trans)-lycopene by isomerization, was increased with storage time at each temperature, and the contents of 13 - or 15 -cis-lycopenes $\left(4,20,30,40^{\circ} \mathrm{C}\right)$ were strongly and negatively correlated with PC1. The contents of cis-phytofluene, ester group 3 and $\zeta$-carotene were irregularly changed in 'Cara Cara' juice during the overall storage period, and their contents at $4,20,30,40^{\circ} \mathrm{C}$ were sorted into different groups. Wibowo et al. proved that $\zeta$-carotene increased during juice storage at different temperatures, while Cortés presented the opposite view $[12,30]$. In this study, the increase of $\zeta$-carotene was just observed at $40{ }^{\circ} \mathrm{C}$.

As presented in the PCA score plot (Figure 3B), the carotenoid profiles of 'Cara Cara' juice stored at different times were clearly divided into four groups. The sterilized juice at 0 week was grouped in the lower right quadrant, showing a positive correlation with PC1 and a negative correlation with PC2. Similarly, the other three groups ( 2 and 4 weeks, 6 and 8 weeks, 12 and 16 weeks) were distributed in the different quadrants, indicating that they have different correlations with PCs. Storage time of each group ( 2 and 4 weeks, 6 and 8 weeks, 12 and 16 weeks) had a similar impact on the change of carotenoid. 


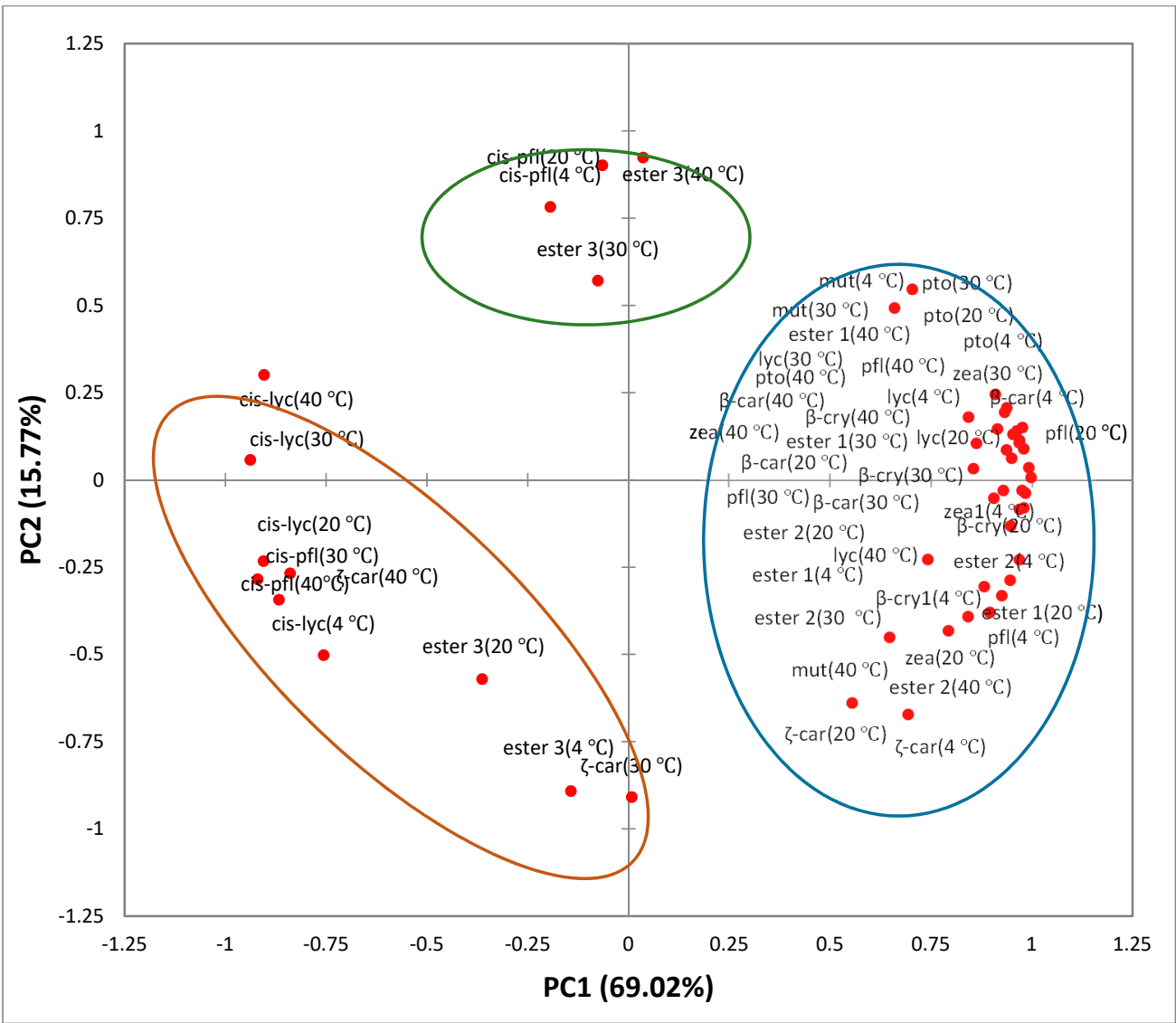

(A)

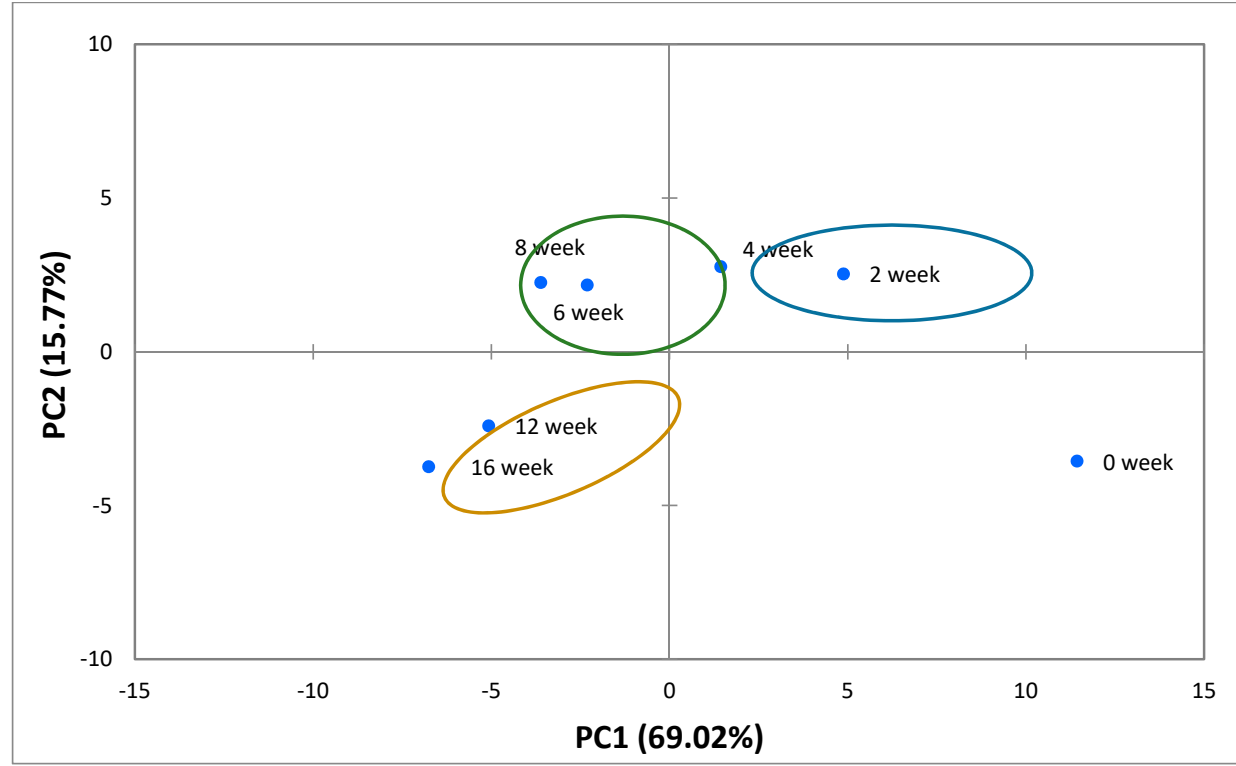

(B)

Figure 3. Principle component analysis (PCA) of carotenoid compounds in 'Cara Cara' juice during 16 weeks of storage at $4,20,30$ and $40^{\circ} \mathrm{C}$. (A) Loading plot of PCA, (B) scores scatter plot of PCA. Note: mut for mutatoxanthin, zea for zeaxanthin, $\beta$-cry for $\beta$-cryptoxanthin, $\zeta$-car for $\zeta$-carotene, $\beta$-car for $\beta$-carotene, cis-lyc for 13- or 15-cis-lycopene, lyc for lycopene, pto for phytoene, pfl for phytofluene, cis-pfl for cis-phytofluene, ester 1 for ester group 1, ester 2 for ester group 2, ester 3 for ester group 3. PC1and PC2 represent the first principal component and the second principal component, respectively. 


\subsection{The Changes of Soluble Sugars in 'Cara Cara' Juice}

Changes of soluble sugar are shown in Table 2. The total soluble sugars were gradually decreased with the improved temperature and prolonged storage. The total soluble sugars were decreased by $1.39 \%, 1.63 \%, 9.33 \%$ and $31.68 \%$ respectively when the juice was stored at $4,20,30$ and $40{ }^{\circ} \mathrm{C}$. It was reported that fructose, glucose and sucrose were greatly degraded in grapefruit juice during its storage at $37^{\circ} \mathrm{C}$ for 16 weeks [19], and the loss of soluble sugars might be related to browning reactions. In the present study, sucrose in 'Cara Cara' juice was minorly hydrolyzed at 4,20 and $30^{\circ} \mathrm{C}$, but it was completely degraded at $40^{\circ} \mathrm{C}$, with fructose and glucose being increased. It was shown that the hydrolysis of sucrose was followed by pseudo first-order reaction, and the hydrolysis progress was correlated with acid concentration and storage time [31]. The increased content of glucose and fructose in 'Cara Cara' juice stored at $40{ }^{\circ} \mathrm{C}$ was not stoichiometrically in line with the hydrolyzed sucrose (Table 2), indicating that hydrolyzate might be partly engaged in Maillard reactions [19].

Table 2. Changes in the content of soluble sugar concentrations $(\mathrm{mg} / \mathrm{mL})$ in 'Cara Cara' juice during 16 weeks of storage at different temperatures.

\begin{tabular}{|c|c|c|c|c|}
\hline Weeks & Fructose & Glucose & Sucrose & Total \\
\hline \multicolumn{5}{|c|}{$4^{\circ} \mathrm{C}$} \\
\hline 0 & $6.96 \pm 0.17 \mathrm{a}$ & $15.15 \pm 0.90 \mathrm{a}$ & $23.22 \pm 1.85 \mathrm{a}$ & $45.33 \pm 2.92 \mathrm{a}$ \\
\hline 2 & $6.95 \pm 0.31 \mathrm{a}$ & $15.09 \pm 0.30 \mathrm{a}$ & $23.16 \pm 1.25 \mathrm{a}$ & $45.21 \pm 1.86 \mathrm{a}$ \\
\hline 4 & $6.90 \pm 0.42 a$ & $14.92 \pm 0.28 \mathrm{a}$ & $23.52 \pm 1.36 \mathrm{a}$ & $45.40 \pm 2.06 \mathrm{a}$ \\
\hline 6 & $7.02 \pm 0.36 \mathrm{a}$ & $15.36 \pm 0.44 \mathrm{a}$ & $23.04 \pm 1.33 \mathrm{a}$ & $45.36 \pm 2.13 \mathrm{a}$ \\
\hline 8 & $6.94 \pm 0.55 \mathrm{a}$ & $15.08 \pm 0.54 \mathrm{a}$ & $22.89 \pm 0.83 \mathrm{a}$ & $44.93 \pm 1.92 \mathrm{a}$ \\
\hline 10 & $7.11 \pm 0.43 \mathrm{a}$ & $15.58 \pm 0.65 \mathrm{a}$ & $22.68 \pm 1.42 \mathrm{a}$ & $45.22 \pm 2.50 \mathrm{a}$ \\
\hline 12 & $6.75 \pm 0.56 a$ & $14.98 \pm 0.36 \mathrm{a}$ & $22.74 \pm 1.88 \mathrm{a}$ & $44.68 \pm 2.80 \mathrm{a}$ \\
\hline 14 & $6.48 \pm 0.38 a$ & $15.97 \pm 0.45 \mathrm{a}$ & $22.88 \pm 1.76 \mathrm{a}$ & $45.81 \pm 2.59 \mathrm{a}$ \\
\hline 16 & $6.54 \pm 0.25 a$ & $15.72 \pm 0.23 \mathrm{a}$ & $22.02 \pm 1.42 \mathrm{a}$ & $44.70 \pm 1.90 \mathrm{a}$ \\
\hline \multicolumn{5}{|c|}{$20{ }^{\circ} \mathrm{C}$} \\
\hline 0 & $6.96 \pm 0.17 a$ & $15.15 \pm 0.90 \mathrm{a}$ & $23.22 \pm 1.85 \mathrm{a}$ & $45.33 \pm 2.92 \mathrm{a}$ \\
\hline 2 & $7.03 \pm 0.12 \mathrm{a}$ & $15.13 \pm 0.14 \mathrm{a}$ & $23.94 \pm 1.67 \mathrm{a}$ & $46.03 \pm 1.93 \mathrm{a}$ \\
\hline 4 & $6.92 \pm 0.42 \mathrm{a}$ & $15.29 \pm 0.64 \mathrm{a}$ & $23.38 \pm 1.79 \mathrm{a}$ & $45.63 \pm 2.85 \mathrm{a}$ \\
\hline 6 & $6.68 \pm 0.88 \mathrm{a}$ & $15.23 \pm 0.92 \mathrm{a}$ & $23.06 \pm 1.15 \mathrm{a}$ & $45.25 \pm 2.95 \mathrm{a}$ \\
\hline 8 & $6.94 \pm 0.37 \mathrm{a}$ & $15.11 \pm 0.78 \mathrm{a}$ & $23.55 \pm 1.84 \mathrm{a}$ & $45.62 \pm 2.99 \mathrm{a}$ \\
\hline 10 & $6.56 \pm 0.21 \mathrm{a}$ & $15.64 \pm 0.44 \mathrm{a}$ & $23.44 \pm 1.38 \mathrm{a}$ & $46.04 \pm 2.03 \mathrm{a}$ \\
\hline 12 & $6.62 \pm 0.54 \mathrm{a}$ & $15.79 \pm 0.59 \mathrm{a}$ & $23.16 \pm 1.47 \mathrm{a}$ & $45.91 \pm 2.60 \mathrm{a}$ \\
\hline 14 & $7.08 \pm 0.52 a$ & $16.07 \pm 0.84 \mathrm{a}$ & $22.43 \pm 1.15 \mathrm{a}$ & $45.46 \pm 2.51 \mathrm{a}$ \\
\hline 16 & $6.84 \pm 0.35 a$ & $16.13 \pm 0.72 \mathrm{a}$ & $21.50 \pm 1.55 \mathrm{a}$ & $44.59 \pm 2.62 \mathrm{a}$ \\
\hline \multicolumn{5}{|c|}{$30{ }^{\circ} \mathrm{C}$} \\
\hline 0 & $6.96 \pm 0.17 a$ & $15.15 \pm 0.90 \mathrm{a}$ & $23.22 \pm 1.85 a b$ & $45.33 \pm 2.92 \mathrm{a}$ \\
\hline 2 & $6.75 \pm 0.29 a$ & $15.16 \pm 0.85 \mathrm{a}$ & $23.60 \pm 1.13 \mathrm{a}$ & $45.72 \pm 2.27 \mathrm{a}$ \\
\hline 4 & $6.79 \pm 0.50 \mathrm{a}$ & $15.71 \pm 0.78 \mathrm{a}$ & $22.12 \pm 2.05 a b$ & $44.79 \pm 3.33 \mathrm{a}$ \\
\hline 6 & $7.14 \pm 0.61 \mathrm{a}$ & $15.85 \pm 0.69 \mathrm{a}$ & $21.81 \pm 1.28 \mathrm{ab}$ & $44.62 \pm 2.58 \mathrm{a}$ \\
\hline 8 & $7.18 \pm 0.65 a$ & $16.00 \pm 1.36 \mathrm{a}$ & $21.03 \pm 1.11 \mathrm{ab}$ & $43.99 \pm 3.12 \mathrm{a}$ \\
\hline 10 & $7.15 \pm 1.85 \mathrm{a}$ & $16.20 \pm 0.46 \mathrm{a}$ & $20.37 \pm 0.64 a b$ & $43.53 \pm 2.95 \mathrm{a}$ \\
\hline 12 & $6.88 \pm 0.47 \mathrm{a}$ & $16.68 \pm 0.96 \mathrm{a}$ & $19.54 \pm 1.57 \mathrm{ab}$ & $43.18 \pm 3.0 \mathrm{a}$ \\
\hline 14 & $7.17 \pm 0.28 \mathrm{a}$ & $16.85 \pm 1.27 \mathrm{a}$ & $19.00 \pm 1.42 a b$ & $42.81 \pm 2.97 \mathrm{a}$ \\
\hline 16 & $7.18 \pm 0.17 \mathrm{a}$ & $16.05 \pm 0.47 \mathrm{a}$ & $18.09 \pm 1.54 \mathrm{~b}$ & $41.10 \pm 2.18 \mathrm{a}$ \\
\hline \multicolumn{5}{|c|}{$40^{\circ} \mathrm{C}$} \\
\hline 0 & $6.96 \pm 0.17 \mathrm{~d}$ & $15.15 \pm 0.90 c$ & $23.22 \pm 1.85 \mathrm{a}$ & $45.33 \pm 2.92 \mathrm{a}$ \\
\hline 2 & $8.10 \pm 0.24 \mathrm{~cd}$ & $17.32 \pm 1.37 \mathrm{c}$ & $20.87 \pm 1.59 \mathrm{a}$ & $45.15 \pm 3.2 \mathrm{a}$ \\
\hline 4 & $8.69 \pm 0.22 b c$ & $18.10 \pm 1.04 \mathrm{cb}$ & $16.97 \pm 1.21 \mathrm{~b}$ & $42.03 \pm 2.47 \mathrm{ab}$ \\
\hline 6 & $9.05 \pm 0.38 a b c$ & $21.89 \pm 1.53 \mathrm{ab}$ & $9.77 \pm 0.24 c$ & $38.62 \pm 2.15 \mathrm{abc}$ \\
\hline 8 & $9.04 \pm 0.81 \mathrm{abc}$ & $22.43 \pm 1.38 \mathrm{a}$ & $5.82 \pm 0.30 \mathrm{~d}$ & $35.21 \pm 2.49 b c$ \\
\hline 10 & $10.01 \pm 0.66 \mathrm{ab}$ & $22.70 \pm 0.79 \mathrm{a}$ & $4.06 \pm 0.11 \mathrm{de}$ & $33.72 \pm 1.56 \mathrm{bc}$ \\
\hline 12 & $9.34 \pm 0.75 \mathrm{abc}$ & $23.43 \pm 1.50 \mathrm{a}$ & $2.77 \pm 0.14 \mathrm{de}$ & $33.16 \pm 2.39 c$ \\
\hline 14 & $9.45 \pm 0.38 a b c$ & $23.42 \pm 1.03 \mathrm{a}$ & $1.59 \pm 0.06 \mathrm{e}$ & $31.88 \pm 1.47 \mathrm{c}$ \\
\hline 16 & $10.78 \pm 0.38 a$ & $24.01 \pm 1.04 \mathrm{a}$ & nd & $30.97 \pm 1.42 c$ \\
\hline
\end{tabular}

Values are expressed as mean \pm standard deviation, $n=3$. Values followed by different letters in the columns are significantly different (Duncan's multiple range tests, $p<0.05$ ). 


\subsection{The Changes of Vitamin C in 'Cara Cara' Juice}

The percent retention of vitamin C in 'Cara Cara' juice during storage is shown in Figure 4, and vitamin $\mathrm{C}$ retention decreased with prolonged storage and increased temperature. No significant loss of vitamin $\mathrm{C}$ was detected in the 'Cara Cara' juice stored at $4{ }^{\circ} \mathrm{C}$ for 16 weeks. The concentration of vitamin C decreased by $23.93 \%, 35 \%$ and $69.58 \%$ respectively when 'Cara Cara' juice was stored at 20,30 and $40{ }^{\circ} \mathrm{C}$ for 16 weeks. The degradation of vitamin $\mathrm{C}$ in citrus juice has been widely studied, and the degradation mode has been fitted to the first-order reaction [32,33]. A similar result was found in our study. The presence of vitamin $\mathrm{C}$ in citrus juice could protect carotenoids from oxidation, and a lower loss of carotenoid was confirmed in vitamin C fortified juice [34].

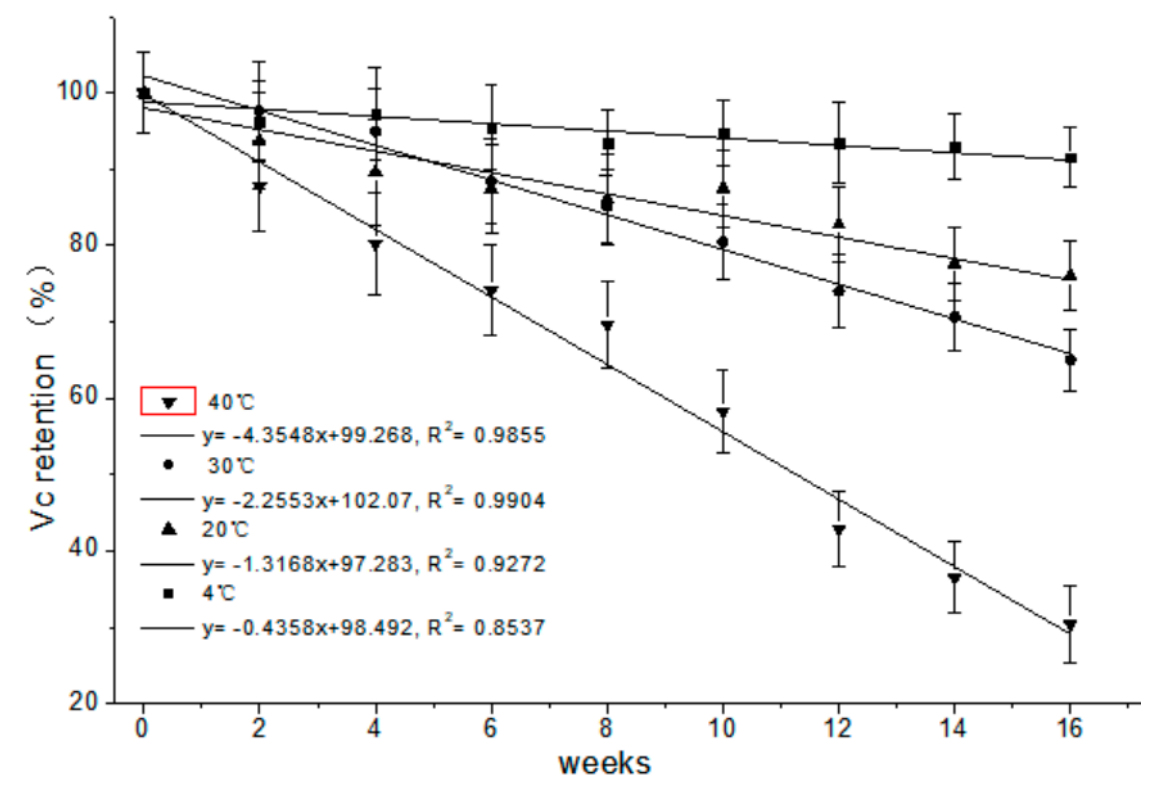

Figure 4. Percent retention of vitamin $C$ in 'Cara Cara' juice during 16 weeks of storage at different temperatures.

\subsection{The Changes of Antioxidants in 'Cara Cara' Juice}

The antioxidants in 'Cara Cara' juice were evaluated in hydrophilic and lipophilic fractions, which represented the antioxidant ability of flavonoids and carotenoids, respectively. It was reported that lipophilic fractions usually displayed much lower antioxidant ability than the hydrophilic fraction in common fruits and vegetables [16,35]. A similar phenomenon was also found in our present study, which might be attributed to the higher content of total flavonoid index than that of the total carotenoid index (Table 1 and Table S1). The changes in both hydrophilic and lipophilic antioxidant abilities in 'Cara Cara' juice during the 16 weeks of storage at different temperatures are shown in Table 3. 
Table 3. Changes of the hydrophilic and lipophilic antioxidant abilities in 'Cara Cara' juice during 16 weeks of storage at different temperatures.

\begin{tabular}{|c|c|c|c|c|}
\hline Weeks & Hydrophilic ABTS ${ }^{1}$ & Hydrophilic DPPH ${ }^{2}$ & Lipophilic ABTS & Lipophilic DPPH \\
\hline \multicolumn{5}{|c|}{$4^{\circ} \mathrm{C}$} \\
\hline 0 & $6.42 \pm 0.44 \mathrm{a}$ & $2.14 \pm 0.06 \mathrm{a}$ & $0.88 \pm 0.03 a$ & $0.76 \pm 0.02 \mathrm{a}$ \\
\hline 4 & $6.23 \pm 0.12 \mathrm{a}$ & $2.09 \pm 0.06 \mathrm{a}$ & $0.81 \pm 0.02 \mathrm{ab}$ & $0.75 \pm 0.03 \mathrm{a}$ \\
\hline 8 & $5.89 \pm 0.31 \mathrm{a}$ & $2.1 \pm 0.06 \mathrm{a}$ & $0.87 \pm 0.02 \mathrm{a}$ & $0.74 \pm 0.05 \mathrm{a}$ \\
\hline 12 & $5.71 \pm 0.21 \mathrm{a}$ & $2.04 \pm 0.06 \mathrm{a}$ & $0.80 \pm 0.03 \mathrm{ab}$ & $0.74 \pm 0.04 \mathrm{a}$ \\
\hline 16 & $5.54 \pm 0.24 \mathrm{a}$ & $1.94 \pm 0.05 a$ & $0.77 \pm 0.05 \mathrm{ab}$ & $0.72 \pm 0.02 \mathrm{a}$ \\
\hline \multicolumn{5}{|c|}{$20^{\circ} \mathrm{C}$} \\
\hline 0 & $6.42 \pm 0.44 \mathrm{a}$ & $2.14 \pm 0.06 \mathrm{a}$ & $0.88 \pm 0.03 a$ & $0.76 \pm 0.02 \mathrm{a}$ \\
\hline 4 & $5.84 \pm 0.31 \mathrm{a}$ & $1.92 \pm 0.05 b$ & $0.82 \pm 0.04 \mathrm{a}$ & $0.73 \pm 0.06 a$ \\
\hline 8 & $5.89 \pm 0.32 \mathrm{a}$ & $1.86 \pm 0.05 b$ & $0.87 \pm 0.06 a$ & $0.69 \pm 0.02 \mathrm{a}$ \\
\hline 12 & $5.81 \pm 0.24 \mathrm{a}$ & $1.82 \pm 0.04 b$ & $0.76 \pm 0.03 a$ & $0.67 \pm 0.03 a$ \\
\hline 16 & $5.48 \pm 0.21 \mathrm{a}$ & $1.64 \pm 0.03 c$ & $0.75 \pm 0.04 a$ & $0.67 \pm 0.04 a$ \\
\hline \multicolumn{5}{|c|}{$30^{\circ} \mathrm{C}$} \\
\hline 0 & $6.42 \pm 0.44 \mathrm{a}$ & $2.14 \pm 0.06 \mathrm{a}$ & $0.88 \pm 0.03 a$ & $0.76 \pm 0.02 \mathrm{a}$ \\
\hline 4 & $6.19 \pm 0.27 \mathrm{a}$ & $1.84 \pm 0.05 b$ & $0.83 \pm 0.06 a$ & $0.74 \pm 0.03 \mathrm{ab}$ \\
\hline 8 & $6.06 \pm 0.32 \mathrm{a}$ & $1.82 \pm 0.03 b$ & $0.82 \pm 0.04 \mathrm{a}$ & $0.66 \pm 0.05 \mathrm{ab}$ \\
\hline 12 & $5.76 \pm 0.28 \mathrm{a}$ & $1.64 \pm 0.04 c$ & $0.76 \pm 0.05 a$ & $0.68 \pm 0.03 \mathrm{ab}$ \\
\hline 16 & $5.53 \pm 0.34 a$ & $1.56 \pm 0.05 c$ & $0.73 \pm 0.03 a$ & $0.62 \pm 0.02 b$ \\
\hline \multicolumn{5}{|c|}{$40^{\circ} \mathrm{C}$} \\
\hline 0 & $6.42 \pm 0.44 \mathrm{a}$ & $2.14 \pm 0.06 a$ & $0.88 \pm 0.03 a$ & $0.76 \pm 0.02 a$ \\
\hline 4 & $6.35 \pm 0.31 \mathrm{~cd}$ & $1.96 \pm 0.06 \mathrm{ab}$ & $0.86 \pm 0.03 \mathrm{ab}$ & $0.72 \pm 0.01 \mathrm{ab}$ \\
\hline 8 & $6.26 \pm 0.32 b c$ & $1.80 \pm 0.05 b c$ & $0.79 \pm 0.02 \mathrm{ab}$ & $0.73 \pm 0.03 \mathrm{ab}$ \\
\hline 12 & $6.18 \pm 0.24 a b c$ & $1.72 \pm 0.03 c$ & $0.75 \pm 0.05 b$ & $0.64 \pm 0.05 a b$ \\
\hline 16 & $5.91 \pm 0.26 \mathrm{abc}$ & $1.61 \pm 0.06 c$ & $0.74 \pm 0.03 b$ & $0.63 \pm 0.04 b$ \\
\hline
\end{tabular}

${ }^{1}$ DPPH: expressed as ascorbic acid equivalent ( $\left.\mu \mathrm{mol} \mathrm{AAE} / \mathrm{mL}\right) ;{ }^{2}$ ABTS: expressed as Trolox equivalent ( $\mu \mathrm{mol}$ $\mathrm{TE} / \mathrm{mL}$ ). Values are expressed as mean $\pm \mathrm{SD}, n=3$. Values followed by different letters in the columns are significantly different (Duncan's multiple range tests, $p<0.05$ ).

The $\mathrm{ABTS}^{+}$and DPPH values for both hydrophilic and lipophilic antioxidants were decreased during storage at different temperatures. After storage for 16 weeks, $\mathrm{ABTS}^{+}$assay values for hydrophilic antioxidants decreased by $13.70 \%, 14.64 \%, 13.86 \%$ and $7.94 \%$ respectively, under $4,20,30,40{ }^{\circ} \mathrm{C}$, while DPPH assay values for hydrophilic antioxidants decreased by $9.34 \%, 23.36 \%, 27.10 \%$ and $24.76 \%$ at corresponding storage temperatures. The $\mathrm{ABTS}^{+}$and $\mathrm{DPPH}$ values for lipophilic antioxidants were relatively stable, and their significant decrease was only observed at the end of storage at $40{ }^{\circ} \mathrm{C}$.

A correlation between flavonoid compositions and antioxidant activity in hydrophilic extracts from 'Cara Cara' juice was explored. A positive correlation was found between the total flavonoid index and hydrophilic antioxidant ability (Table 4), in accordance with a previous study [36]. Each individual flavonoid was significantly and positively correlated with tested antioxidant activities at $p<0.01$ level (Table 4). Therefore, flavonoid compounds in 'Cara Cara' juice were the important contributions to the hydrophilic antioxidant ability. Correlations between carotenoid compositions and lipophilic antioxidant activities of 'Cara Cara' juice are presented in Table 5. Consisting of zeaxanthin, $\beta$-cryptoxanthin, lycopene, phytoene, phytofluene, ester group 1, ester group 2 and the total carotenoid index were significantly and positively correlated with the tested bioactivities at $p<0.01$. $\beta$-carotene correlated with $\mathrm{ABTS}^{+}$capacity and DPPH scavenging at $p<0.01$ level and $p<0.05$ level, respectively. $\zeta$-carotene, 13- or 15-cis-lycopene, cis- phytofluene and ester group 3 were negatively correlated with the tested bioactivities. The result suggested that zeaxanthin, $\beta$-cryptoxanthin, lycopene, phytoene, phytofluene, ester group 1 and ester group 2 were contributors to the lipophilic antioxidant ability of ‘Cara Cara' juice. 
Table 4. Correlation matrix between flavonoid compositions and antioxidant activity in hydrophilic extracts from stored 'Cara Cara' juice.

\begin{tabular}{ccc}
\hline & Hydrophilic ABTS & Hydrophilic DPPH $^{+}$ \\
\hline apigenin-6,8-di-C-glucoside & $0.752^{* *}$ & $0.857^{* *}$ \\
narirutin-4'-O-glucoside & $0.808^{* *}$ & $0.870^{* *}$ \\
narirutin & $0.702^{* *}$ & $0.901^{* *}$ \\
hesperidin & $0.699^{* *}$ & $0.874^{* *}$ \\
didymin & $0.608^{* *}$ & $0.882^{* *}$ \\
total flavonoid index & $0.742^{* *}$ & $0.910^{* *}$ \\
\hline$* *$ indicated the correlated factors with each other reached significant level $p<0.01$
\end{tabular}

** indicated the correlated factors with each other reached significant level, $p<0.01$.

Table 5. Correlation matrix between carotenoid compositions and antioxidant activity in lipophilic extracts from stored 'Cara Cara' juice.

\begin{tabular}{|c|c|c|}
\hline & Lipophilic ABTS $^{+}$ & Lipophilic DPPH \\
\hline mutatoxanthin & 0.420 & 0.391 \\
\hline zeaxanthin & $0.724^{* *}$ & $0.634^{* *}$ \\
\hline$\beta$-cryptoxanthin & $0.704^{* *}$ & $0.604^{* *}$ \\
\hline$\zeta$-carotene & -0.178 & -0.195 \\
\hline$\beta$-carotene & $0.640 * *$ & $0.558 *$ \\
\hline 13- or 15-cis-lycopene & $-0.655^{* *}$ & $-0.666^{* *}$ \\
\hline lycopene & $0.652^{* *}$ & $0.600^{* *}$ \\
\hline phytoene & $0.698^{* *}$ & $0.619^{* *}$ \\
\hline phytofluene & $0.760 * *$ & $0.848^{* *}$ \\
\hline cis-phytofluene & $-0.629 * *$ & $-0.764 * *$ \\
\hline ester group 1 & $0.865^{* *}$ & $0.799^{* *}$ \\
\hline ester group 2 & $0.703^{* *}$ & $0.645^{* *}$ \\
\hline ester group 3 & -0.225 & -0.293 \\
\hline total carotenoid index & $0.732 * *$ & $0.664^{* *}$ \\
\hline
\end{tabular}

* indicated the correlated factors with each other reached significant level, $p<0.05 .{ }^{* *}$ indicated the correlated factors with each other reached significant level, $p<0.01$.

\section{Conclusions}

The micronutrients in 'Cara Cara' juice were investigated during storage at $4,20,30$ and $40{ }^{\circ} \mathrm{C}$ for a period of 16 weeks. Total flavonoid and carotenoid indexes showed slight degradation at each temperature, while vitamin $\mathrm{C}$ and soluble sugar degraded intensively, especially at $40{ }^{\circ} \mathrm{C}$ storage. Although the total carotenoids were stable at each storage temperature, most carotenoid esters were significantly degraded and fitted by biexponential function. Specifically, the ester group 2 with epoxy structures quickly decreased in the first four weeks at all storage temperatures, while the ester group 1 (belonged to $\beta$-cryptoxanthin ester) degraded gradually. The combined degrading rates of the two type of esters might be further applied to estimate the storage time of 'Cara Cara' juice. Total flavonoid and carotenoid indexes in stored 'Cara Cara' juice were positively correlated with hydrophilic and lipophilic antioxidant abilities. This study provided information on changes of flavonoid, carotenoids, vitamin $C$ and sugar in 'Cara Cara' juice during storage at moderate and elevated temperatures, which might be useful for the quality prediction of 'Cara Cara' juice during storage.

Supplementary Materials: The following are available online at http://www.mdpi.com/2304-8158/8/9/417/s1, Figure S1: Biexponential fitting with eq 1 of the experimental data obtained for the degradation of ester group 1 in Cara Cara juice during 16 weeks storage at $4{ }^{\circ} \mathrm{C}(\mathrm{A}), 20^{\circ} \mathrm{C}(\mathrm{B}), 30^{\circ} \mathrm{C}(\mathrm{C})$ and $40{ }^{\circ} \mathrm{C}(\mathrm{D})$, respectively. Figure S2: Biexponential fitting with eq 1 of the experimental data obtained for the degradation of ester group 2 in Cara Cara juice during 16 weeks storage at $4{ }^{\circ} \mathrm{C}(\mathrm{A}), 20^{\circ} \mathrm{C}(\mathrm{B}), 30^{\circ} \mathrm{C}(\mathrm{C})$ and $40{ }^{\circ} \mathrm{C}(\mathrm{D})$, respectively. Table S1: Changes in the content of carotenoids $(\mu \mathrm{g} / \mathrm{mL})$ in 'Cara Cara' juice during 16 weeks of storage at different temperature.

Author Contributions: Data curation, L.L.; Methodology, S.X.; Project administration, S.W.; Supervision, D.Y.; Writing-original draft, Q.L.

Funding: National Natural Science Foundation of China: 31571847. 
Acknowledgments: This work was supported by National Natural Science Foundation of China (grant number 31571847).

Conflicts of Interest: The authors declare no conflict of interest.

\section{References}

1. Wibowo, S.; Grauwet, T.; Santiago, J.S.; Tomic, J.; Vervoort, L.; Hendrickx, M.; Van Loey, A. Quality changes of pasteurised orange juice during storage: A kinetic study of specific parameters and their relation to colour instability. Food Chem. 2015, 187, 140-151. [CrossRef] [PubMed]

2. Ghanim, H.; Sia, C.L.; Upadhyay, M.; Korzeniewski, K.; Viswanathan, P.; Abuaysheh, S.; Mohanty, P.; Dandona, P. Orange juice neutralizes the proinflammatory effect of a high-fat, high-carbohydrate meal and prevents endotoxin increase and Toll-like receptor expression. Am. J. Clin. Nutr. 2010, 91, 940-949. [CrossRef] [PubMed]

3. Aschoff, J.K.; Kaufmann, S.; Kalkan, O.; Neidhart, S.; Carle, R.; Schweiggert, R.M. In Vitro Bioaccessibility of Carotenoids, Flavonoids, and Vitamin C from Differently Processed Oranges and Orange Juices (Citrus sinensis (L.) Osbeck). J. Agric. Food Chem. 2015, 63, 578-587. [CrossRef] [PubMed]

4. Du, J.; Cullen, J.J.; Buettner, G.R. Ascorbic acid: Chemistry, biology and the treatment of cancer. Biochim. Biophys. Acta Rev. Cancer 2012, 1826, 443-457. [CrossRef]

5. Abuajah, C.I.; Ogbonna, A.C.; Osuji, C.M. Functional components and medicinal properties of food: A review. J. Food Sci. Technol. 2015, 52, 2522-2529. [CrossRef] [PubMed]

6. Lee, H.S. Characterization of Carotenoids in Juice of Red Navel Orange (Cara Cara). J. Agric. Food Chem. 2001, 49, 2563-2568. [CrossRef] [PubMed]

7. Lu, Q.; Huang, X.; Lv, S.; Pan, S. Carotenoid profiling of red navel orange "Cara Cara" harvested from five regions in China. Food Chem. 2017, 232, 788-798. [CrossRef] [PubMed]

8. Rapisarda, P.; Bianco, M.L.; Pannuzzo, P.; Timpanaro, N. Effect of cold storage on vitamin C, phenolics and antioxidant activity of five orange genotypes (Citrus sinensis (L.) Osbeck). Postharvest Biol. Technol. 2008, 49, 348-354. [CrossRef]

9. Klimczak, I.; Małecka, M.; Szlachta, M.; Gliszczyńska-Świgło, A. Effect of storage on the content of polyphenols, vitamin $C$ and the antioxidant activity of orange juices. J. Food Compos. Anal. 2007, 20, 313-322. [CrossRef]

10. Lu, Q.; Lv, S.; Peng, Y.; Zhu, C.; Pan, S. Characterization of phenolics and antioxidant abilities of red navel orange "Cara Cara" harvested from five regions of China. Int. J. Food Prop. 2018, 21, 1107-1116. [CrossRef]

11. Brasili, E.; Chaves, D.F.S.; Xavier, A.A.O.; Mercadante, A.Z.; Hassimotto, N.M.A.; Lajolo, F.M. Effect of Pasteurization on Flavonoids and Carotenoids in Citrus sinensis (L.) Osbeck cv. 'Cara Cara' and 'Bahia' Juices. J. Agric. Food Chem. 2017, 65, 1371-1377. [CrossRef] [PubMed]

12. Wibowo, S.; Vervoort, L.; Tomic, J.; Santiago, J.S.; Lemmens, L.; Panozzo, A.; Grauwet, T.; Hendrickx, M.; Van Loey, A. Colour and carotenoid changes of pasteurised orange juice during storage. Food Chem. 2015, 171, 330-340. [CrossRef] [PubMed]

13. Mezzomo, N.; Ferreira, S.R.S. Carotenoids Functionality, Sources, and Processing by Supercritical Technology: A Review. J. Chem. 2016, 2016, 16. [CrossRef]

14. Plaza, L.; Sánchez-Moreno, C.; De Ancos, B.; Elez-Martínez, P.; Martín-Belloso, O.; Cano, M.P. Carotenoid and flavanone content during refrigerated storage of orange juice processed by high-pressure, pulsed electric fields and low pasteurization. LWT Food Sci. Technol. 2011, 44, 834-839. [CrossRef]

15. Lu, Q.; Peng, Y.; Zhu, C.; Pan, S. Effect of thermal treatment on carotenoids, flavonoids and ascorbic acid in juice of orange cv. Cara Cara. Food Chem. 2018, 265, 39-48. [CrossRef] [PubMed]

16. Vallverdú-Queralt, A.; Arranz, S.; Casals-Ribes, I.; Lamuela-Raventós, R.M. Stability of the Phenolic and Carotenoid Profile of Gazpachos during Storage. J. Agric. Food Chem. 2012, 60, 1981-1988. [CrossRef] [PubMed]

17. Vallverdú-Queralt, A.; Medina-Remón, A.; Andres-Lacueva, C.; Lamuela-Raventos, R.M. Changes in phenolic profile and antioxidant activity during production of diced tomatoes. Food Chem. 2011, 126, 1700-1707. [CrossRef] [PubMed] 
18. Stinco, C.M.; Fernández-Vázquez, R.; Escudero-Gilete, M.L.; Heredia, F.J.; Meléndez-Martínez, A.J.; Vicario, I.M. Effect of Orange Juice's Processing on the Color, Particle Size, and Bioaccessibility of Carotenoids. J. Agric. Food Chem. 2012, 60, 1447-1455. [CrossRef]

19. Lee, H.S.; Nagy, S. Quality Changes and Nonenzymic Browning Intermediates in Grapefruit Juice During Storage. J. Food Sci. 1988, 53, 168-172. [CrossRef]

20. Mohamed Ahmed, M.V.O.; Bouna, Z.E.O.; Mohamed Lemine, F.M.; Djeh, T.K.O.; Mokhtar, T.; Mohamed Salem, A.O. Use of multivariate analysis to assess phenotypic diversity of date palm (Phoenix dactylifera L.) cultivars. Sci. Hortic. 2011, 127, 367-371. [CrossRef]

21. Dhuique-Mayer, C.; Caris-Veyrat, C.; Ollitrault, P.; Curk, F.; Amiot, M.-J. Varietal and Interspecific Influence on Micronutrient Contents in Citrus from the Mediterranean Area. J. Agric. Food Chem. 2005, 53, 2140-2145. [CrossRef] [PubMed]

22. Persic, M.; Mikulic-Petkovsek, M.; Slatnar, A.; Veberic, R. Chemical composition of apple fruit, juice and pomace and the correlation between phenolic content, enzymatic activity and browning. LWT Food Sci. Technol. 2017, 82, 23-31. [CrossRef]

23. Dhuique-Mayer, C.; Tbatou, M.; Carail, M.; Caris-Veyrat, C.; Dornier, M.; Amiot, M.J. Thermal Degradation of Antioxidant Micronutrients in Citrus Juice: Kinetics and Newly Formed Compounds. J. Agric. Food Chem. 2007, 55, 4209-4216. [CrossRef] [PubMed]

24. Chen, P.X.; Tang, Y.; Zhang, B.; Liu, R.; Marcone, M.F.; Li, X.; Tsao, R. 5-Hydroxymethyl-2-furfural and Derivatives Formed during Acid Hydrolysis of Conjugated and Bound Phenolics in Plant Foods and the Effects on Phenolic Content and Antioxidant Capacity. J. Agric. Food Chem. 2014, 62, 4754-4761. [CrossRef] [PubMed]

25. Meléndez-Martínez, A.J.; Britton, G.; Vicario, I.M.; Heredia, F.J. The complex carotenoid pattern of orange juices from concentrate. Food Chem. 2008, 109, 546-553. [CrossRef]

26. Hadjal, T.; Dhuique-Mayer, C.; Madani, K.; Dornier, M.; Achir, N. Thermal degradation kinetics of xanthophylls from blood orange in model and real food systems. Food Chem. 2013, 138, 2442-2450. [CrossRef]

27. Cooperstone, J.L.; Francis, D.M.; Schwartz, S.J. Thermal processing differentially affects lycopene and other carotenoids in cis-lycopene containing, tangerine tomatoes. Food Chem. 2016, 210, 466-472. [CrossRef] [PubMed]

28. Nguyen, M.; Francis, D.; Schwartz, S. Thermal isomerisation susceptibility of carotenoids in different tomato varieties. J. Sci. Food Agric. 2001, 81, 910-917. [CrossRef]

29. Zepka, L.Q.; Mercadante, A.Z. Degradation compounds of carotenoids formed during heating of a simulated cashew apple juice. Food Chem. 2009, 117, 28-34. [CrossRef]

30. Cortés, C.; Torregrosa, F.; Esteve, M.J.; Frígola, A. Carotenoid Profile Modification during Refrigerated Storage in Untreated and Pasteurized Orange Juice and Orange Juice Treated with High-Intensity Pulsed Electric Fields. J. Agric. Food Chem. 2006, 54, 6247-6254. [CrossRef] [PubMed]

31. Akhavan, I.; Wrolstad, R.E. Variation of sugars and acids during ripening of pears and in the production and storage of pear concentrate. J. Food Sci. 1980, 45, 499-501. [CrossRef]

32. Tiwari, B.K.; O’Donnell, C.P.; Muthukumarappan, K.; Cullen, P.J. Ascorbic acid degradation kinetics of sonicated orange juice during storage and comparison with thermally pasteurised juice. LWT Food Sci. Technol. 2009, 42, 700-704. [CrossRef]

33. Burdurlu, H.S.; Koca, N.; Karadeniz, F. Degradation of vitamin C in citrus juice concentrates during storage. J. Food Eng. 2006, 74, 211-216. [CrossRef]

34. Choi, M.H.; Kim, G.H.; Lee, H.S. Effects of ascorbic acid retention on juice color and pigment stability in blood orange (Citrus sinensis) juice during refrigerated storage. Food Res. Int. 2002, 35, 753-759. [CrossRef] 
35. Wu, X.; Beecher, G.R.; Holden, J.M.; Haytowitz, D.B.; Gebhardt, S.E.; Prior, R.L. Lipophilic and Hydrophilic Antioxidant Capacities of Common Foods in the United States. J. Agric. Food Chem. 2004, 52, 4026-4037. [CrossRef] [PubMed]

36. Miao, J.; Li, X.; Zhao, C.; Gao, X.; Wang, Y.; Gao, W. Active compounds, antioxidant activity and $\alpha$-glucosidase inhibitory activity of different varieties of Chaenomeles fruits. Food Chem. 2018, 248, 330-339. [CrossRef] [PubMed]

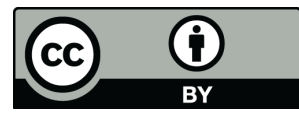

(C) 2019 by the authors. Licensee MDPI, Basel, Switzerland. This article is an open access article distributed under the terms and conditions of the Creative Commons Attribution (CC BY) license (http://creativecommons.org/licenses/by/4.0/). 